Portland State University

PDXScholar

9-29-1995

\title{
A Comparison of High School Student and Adult Expectations of Leader Behavior
}

Charles Edward Beyer

Portland State University

Follow this and additional works at: https://pdxscholar.library.pdx.edu/open_access_etds

Part of the Psychology Commons

Let us know how access to this document benefits you.

\section{Recommended Citation}

Beyer, Charles Edward, "A Comparison of High School Student and Adult Expectations of Leader Behavior" (1995). Dissertations and Theses. Paper 4972.

https://doi.org/10.15760/etd.6848

This Thesis is brought to you for free and open access. It has been accepted for inclusion in Dissertations and Theses by an authorized administrator of PDXScholar. Please contact us if we can make this document more accessible: pdxscholar@pdx.edu. 


\section{THESIS APPROVAL}

The abstract and thesis of Charles Edward Beyer for the Master of Science in

Psychology were presented September 29, 1995, and accepted by the thesis

committee and the department.

COMMITTEE APPROVALS:

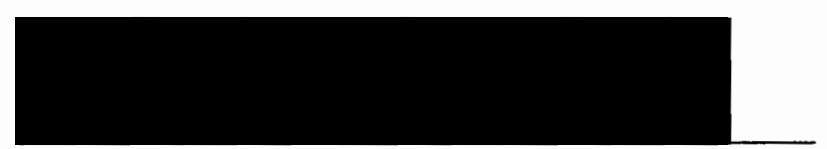

Dean Frost, Chair

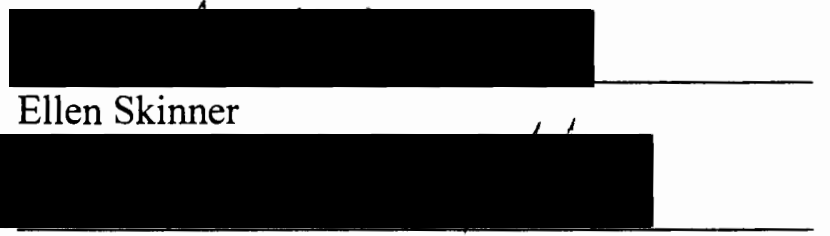

Donald Truxillo

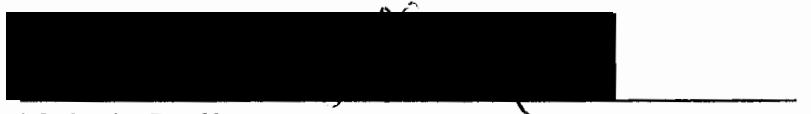

Valerie Dull

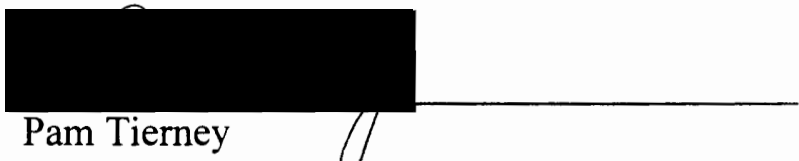

Representative of the Office of Graduate Studies

DEPARTMENTAL APPROVAL:

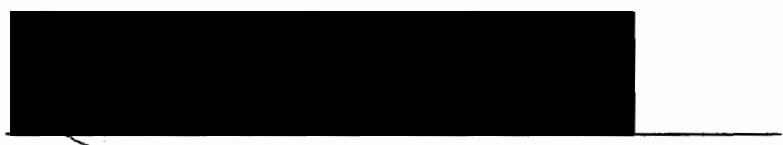

James Paulson, Chair

Department of Psychology

ACCEPTED FOR PORTLAND STATE UNIVERSITY BY THE LIBRARY

by

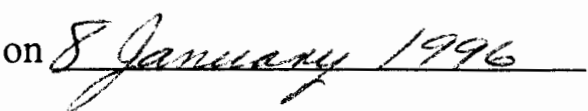




\section{ABSTRACT}

An abstract of the thesis of Charles Edward Beyer for the Master of Science in Psychology presented September 29, 1995.

Title: A Comparison of High School Student and Adult Expectations of Leader Behavior

The purpose of this study was to determine whether the type of activity or type of role played within an activity influenced expectations of leader behavior. One-hundred forty-five adult leaders, student leaders, and student group members of high school basketball teams, bands, journalism staffs, and student government associations were surveyed regarding their expectations of ideal adult leaders, student leaders, and leaders in general across eight leadership constructs. Multivariate analysis of variance results suggest that the type of activity influences group expectations of adult activity leaders. Results also suggest that women expect more consideration from student leaders and leaders in general than do males. Further analyses determined that students expect more initiation of structure, networking, and expertise from adult learers than student leaders. 
A COMPARISON OF HIGH SCHOOL STUDENT AND ADULT

\section{EXPECTATIONS OF LEADER BEHAVIOR}

$$
\text { by }
$$

\section{CHARLES EDWARD BEYER}

A thesis submitted in partial fulfillment of the requirements for the degree of

MASTER OF SCIENCE

in

PSYCHOLOGY

Portland State University

1995 


\section{TABLE OF CONTENTS}

PAGE

A Comparison of High School Student and Adult Expectation of Leader Behavior... 4

Impetus for Leadership Education $\ldots \ldots \ldots \ldots \ldots \ldots \ldots \ldots \ldots \ldots \ldots \ldots \ldots \ldots \ldots$

The State of Leadership Education...................................... 5

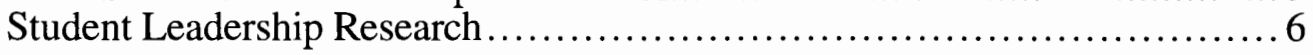

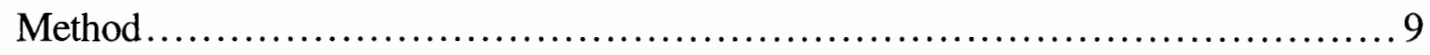

Stage I: Pilot Study .......................................... 9

Stage II: Research Questionnaire..................................11

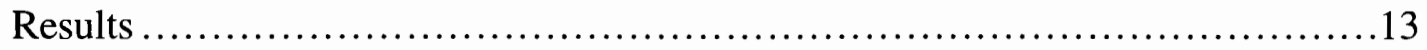

Descriptive Statistics ............................................13

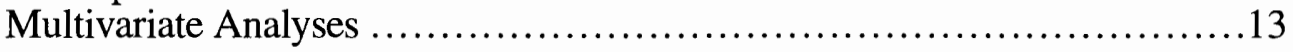

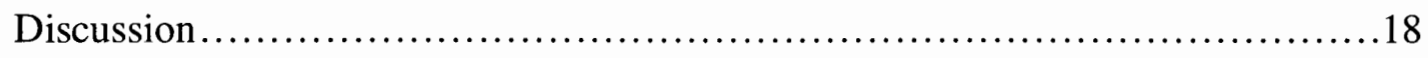

Differences Within Subjects on Types of Leaders Rated ..................26

Future Research Directions.......................................27

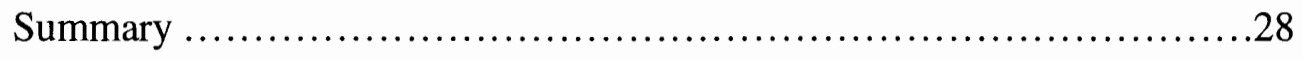

References....................................................... 30

Appendices

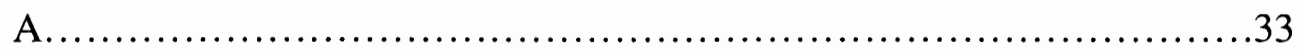

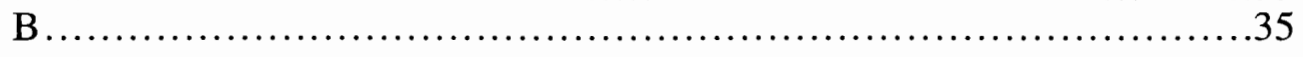


Student and Adult Leadership Expectations

\section{A Comparison of High School Student and Adult Expectations}

\section{of Leader Behavior}

Impetus for Leadership Education

Leadership education has become an integral part of high school student education. Between 1979 and 1983, the number of high schools offering classes devoted to leadership education rose from 15 to 25 percent nationwide (Simmons, 1983). A survey conducted in 1984 by the Oregon Department of Education found that $58 \%$ of its largest schools (class $4 \mathrm{~A}$ ) offered a leadership class. Several curricula, training programs, workshops, and camps have been established in order to answer the increased demand for leadership education (Findorff, 1991; Gano, 1993; Magoon, 1981; Parker, 1983; Stiles, 1986; Washburn \& Hammond, 1982).

The most recent demand for leadership education has come from the Secretary's Commission on Achieving Necessary Skills (SCANS - U.S. Department of Labor, 1991). The purpose of the first SCANS report, What Work Requires of Schools, was to identify the necessary skills for high school students to successfully make the transition between school and work. In their report recommendations, the commission specified "exercises leadership" as one of 20 workplace competencies to be integrated into mainstream curricula. The report also listed competencies often associated with leadership including "manages human resources", "manages material and facility resources", "negotiates to arrive at a decision", and "interprets and communicates information." 
In addition to facilitating the transition from school to work, leadership education programs aim to meet objectives and to teach skills (e.g., problem solving, organizing, evaluating) that are vital to all students in any educational program (Young, 1977). Further, the value placed on leadership education and experience is reflected by the fact that these are listed as criteria within numerous college admission and scholarship applications (Porter, 1981).

The State of Leadership Education

Many of the current leadership curricula are devoted to such things as parliamentary procedure and public speaking. Other curricula treat high school students as "mini managers." As one teacher put it, "Only instead of talking about running a multibillion-dollar business, we're talking about raising $\$ 300$ for a high school dance" (Simmons, 1983).

The assumptions of such programs are that students and adults have similar needs for leadership and interpretations of what it means to be a leader (i.e. implicit leadership theories). While these may be worthwhile exercises, they fail to get at important aspects of the nature of leadership. They tend to serve the needs of student government oriented school leaders over such leaders as the yearbook editor, the team captain, and the marching band drum major. They also do little to serve the needs of students leaving high school and moving directly into the work force. Perhaps most importantly, they reflect many untested assumptions about the development of leadership perceptions in late adolescence and young adulthood. 


\section{Student Leadership Research}

A number of high school leadership education programs have surfaced in recent years, yet there remains a dearth of research in the field. According to Bass (1990), most research examining student leadership is centered on college students. As a result, the high school leadership curricula in existence have very little basis in leadership research.

This study will explore leadership at the high school level. Since there are few high school studies in existence to use as a foundation to build upon, the present study will follow the lead of traditional leadership research. As such, the leaders' situational contexts, roles, and gender will be explored.

Situational Context. Through their own social experiences, people develop "implicit leadership theories" (Eden \& Leviatan, 1975; Rush, Thomas, \& Lord, 1977). That is, they make assumptions concerning the behaviors, traits, and abilities needed for effective leadership. Students form mental representations or schemata for categorizing leaders (Nye \& Forsyth, 1991). They develop leader prototypes -cognitive summaries of the most common features of leaders. Prototypes are amalgams of all the elements one thinks of when considering the notion of "leader." From these prototypes, students form expectations of leader behavior. In Calder's (1977) proposal of a new theory of leadership he states

"Just what these leadership expectations are is an empirical question. Certainly the meaning of leadership is particular to a 
given group of actors and their situational context over time."

(Emphasis added.)

Thus, the present study seeks to answer the empirical question of what leadership expectations, or prototypes, do high school students hold.

Specifically, it will aid in determining the meaning of leadership to a particular group of students and student leaders in their various situational contexts. In this study, situational context refers to the type of activity in which the students and adults are involved. Such information would be helpful in determining the content of a high school leadership course.

Role. As previously mentioned, current high school leadership education places a great deal of emphasis on experience. That is, the underlying belief is that to really learn about leadership and what it means to be an effective leader, one must play the part of a leader. This study will explore the assumption that the role of individuals within an activity influences the expectations of leader behaviors. The roles examined here will include that of the adult activity leader, student leader, and student group member.

Gender. Between 1972 and 1986, the percentage of women in managerial positions has risen from 19 to over 30 percent (Hymowitz \& Schellhardt, 1986). As the percentage of women in leadership positions rises in the work force, it becomes increasingly more relevant to examined differences between male and female leaders. Research has supplied evidence that both supports and refutes differences between 
men and women leaders (Bass, 1990; Eagly \& Johnson, 1990). No research could be found that has explored differences between male and female expectations for leaders at the high school level.

Behavior and Ability. As this study is focused primarily on implications for leadership instruction, it explores the "teachable" aspects of leadership, namely leader behavior. Education provides a means to develop abilities and change behaviors. Thus, leadership traits (e.g., extroversion, integrity), which are generally considered to be more stable, are not addressed here. The current research is concerned with implicit leadership theories of leader behavior and not with actual leader behavior.

Drawing from a synthesis of corresponding taxonomies of leadership presented by Yukl (1989), eight types of leader behaviors/abilities have been selected as relevant constructs for investigation. These constructs include:

- Supporting - Showing consideration.

- Accepting responsibility - Taking risks; Confidence.

- Motivating - Setting goals.

- Initiating structure - Organizing and directing.

- Problem solving - Making decisions.

- Networking - Coordinating.

- Building teams - Managing conflict/promoting interaction.

- Expertise - Task competence.

In sum, it is the purpose of the present research to answer the following questions: Does leadership have a different meaning for high school students than it does for work-experienced adults? Specifically, are there significant differences in 
ratings of ideal leadership behavior between students, student leaders, and adult leaders? Are there significant differences in ratings of ideal leadership behavior between student groups (i.e., athletic teams, clubs, student government groups, performance groups, and work groups) or between males and females?

\section{METHOD}

The research was carried out in two stages. Stage I was a pilot study to determine if behavioral items on the Stage II questionnaire were perceived by subjects as belonging to their corresponding constructs. For example, did subjects agree that the item, "A leader tries to bring out the best work of group members" belonged to the "Motivation" construct. (See Appendix A for a complete list of questionnaire leadership statement items and their associated constructs.) Stage II was aimed at answering the primary research questions presented above. Responding to a questionnaire, students reported the frequency with which ideal leaders perform specific behaviors or possess certain abilities.

\section{Stage I: Pilot Study}

Sample. Subjects were juniors and seniors selected from a metropolitan 4A high school. The sample consisted of ten high school student leaders - two students (male and female) from the following five activity groups: team (basketball), club (yearbook or newspaper), government (associated student body), performance (marching band), and work (off campus employment). Subjects who met the criteria volunteered to participate. 
Measure. The Stage I measure consisted of a stack of 40 index cards with a different leadership statement printed on each card (e.g., "A leader is friendly and approachable"; "A leader uses available outside resources"; "A leader encourages teamwork"). Five statements (items) were used for each of the eight leadership constructs. Some items were taken from the Leader Behavior Description Questionnaire Form XII (Stogdill, 1963) and modified for use here.

Procedure. The high school principal was contacted to gain permission to conduct the research within the high school and to obtain names of students that met the subject criteria. The principal referred the researcher to the school's leadership class instructor.

Subjects were given a document containing a brief explanation as to the purpose of the study and a voluntary consent form. The researcher reviewed the document with them, emphasizing the voluntary and confidential nature of the study and checking for understanding.

Each subject was given a sheet containing brief definitions (one or two sentences) of the eight leadership constructs. Each subject also received a set of the 40 index cards. Subjects sorted the leadership statements into piles that they felt corresponded to the leadership constructs.

Analysis and Results. Cohen's kappa was calculated to determine subject agreement with the true classification of the items. This index measures agreement over and above the agreement to be expected if judgements were strictly independent 
Student and Adult Leadership Expectations

(Hays, 1991). The mean of the ten pair-wise kappas was 0.82 . This indicates good item reliability.

\section{Stage II: Research Questionnaire}

Sample. Subjects were selected from 14 northwest urban and rural 4A high schools as well as surrounding area restaurants. An adult leader, student leader, and three student group members were sampled from each high school or restaurant for each activity group: teams (basketball), clubs (journalism), government (associated student body), performance (band), and work (food service). Adult and student leaders were selected by subject criteria (i.e. they were the leaders of their respective groups). Student activity group members were selected by the adult leaders. The only criteria suggested to adult leaders for selecting group member participants was that the activity group members should have been a member of the group for at least one year and, when possible, they try to select both males and females.

Of the 350 surveys that were distributed, 157 were returned. Four of the surveys were unusable (i.e., incomplete) and excluded from further analyses. Of the 70 surveys distributed to the work group (food service), only eight were returned. Thus, the work group was dropped from further analyses due to a low return rate.

Of the remaining 280 surveys distributed to the team, club, performance, and government activity groups, 145 were returned in usable condition (52\%). Fifty-five males and 76 females returned surveys, and 14 subjects did not indicate their gender. Three students were in the 9 th grade, 22 students were in 10th grade, 31 students were 
in 11 th, and 44 students were in 12th. The average age of the student subjects was 16.8 years. Six students did not report their grade level or age. The average age of the adult subjects was 41.8 years old. Twelve adults did not report their age. See Table 1a in Appendix B for a breakdown of subject totals by role (adult leader, student leader, activity group member) and activity. Table $1 \mathrm{~b}$ shows subject gender frequencies for roles and activities.

Measure. The Stage II measure consisted of a questionnaire listing all 40 leadership statements. Subjects were asked to think about how frequently an ideal student leader of their group would engage in the behavior described by the leadership statement. Subjects rated each item using a 5-point Likert-type scale. For example:

An ideal student leader treats all group members as his or her equal.

$\begin{array}{crrcc}\text { Never } & \text { Seldom } & & \text { Sometimes } & \text { Often } \\ 1 & 2 & 3 & 4 & 5\end{array}$

Subjects rated the 40 items three times in total, each time considering a different target as an ideal leader. They first considered the ideal student leader in their ratings, then considered the ideal adult advisor/coach/supervisor as leader, and finally considered an ideal leader in general.

Procedure. Questionnaires were distributed to adult leaders at their schools along with cover letters describing the voluntary and confidential nature of the study. Adults were asked to anonymously complete the questionnaire themselves and to 
distribute copies of the questionnaire and cover letter to three student group members and the group's student leader. After subjects completed the questionnaire anonymously, they returned them in a supplied postage-paid envelope.

\section{RESULTS}

\section{Descriptive Statistics}

A reliability analysis was performed on item ratings for each group of five leadership statement items within a construct. This analysis was performed for each of the three target surveys. Table 2, Table 3 , and Table 4 provide descriptive statistics, estimates of internal consistency reliability (Cronbach's alpha), and correlations among the leadership constructs for each target leader.

All construct items demonstrated acceptable levels of internal consistency reliability across all targets with the exception of the modest level of internal reliability shown by items in the Responsibility construct for the Student Leader as the target. The combination of favorable alpha levels and the Cohen's kappa results from Stage I establishes satisfactory internal consistency reliability.

\section{Multivariate Analyses}

Each subject's ratings for the five leadership statement items associated with a particular construct were summed to create a new construct variable (possible range: 5 to 25) for each leader target. For example, the scores of all five items associated with consideration/support on the "Student Leader as Target" questionnaire were summed to form a variable called "slconsid". (See Table 5 for a list of all such 
Student and Adult Leadership Expectations

variables.) All multivariate analyses utilized these aggregate variables as measures of leadership expectations.

Three $3 \times 4$, Role (Adult leader, Student Leader, Student group member) $\mathrm{x}$ Activity (Band, Journalism, Student government, Basketball), MANOVAs were performed: one for student leaders as targets, one for adult leaders as targets, and one for general leaders as targets. Each MANOVA was performed to determine if subjects' leader expectations differed depending on their role and/or activity. Three one-way MANOVAs were also performed to determine if male and female students differed on leader expectations.

Student Leader as Target. Results of the $3 \times 4$ MANOVA revealed significant effects by activity (Wilks' $\Lambda=.74, F(24,360)=1.63, p<.05$ ). Differences by role were not significant (see Table 6).

The univariate analysis for activity shows that subjects significantly differ on expectations of student leader problem solving/decision making $(F(3,131)=3.42$, $\mathrm{p}<.05$ ). Only one significant comparison was found using Bonferroni's post-hoc procedure. Those involved in Journalism $(\mathrm{M}=21.3)$ expect more problem solving behavior from student leaders than do those involved in Band $(M=19.8)$.

A MANOVA testing differences by student gender was significant (Wilks' $\Lambda=.84, \mathrm{~F}(8,90)=2.16, \mathrm{p}<.05$; see Table 7$)$. The univariate analysis for student gender reveals that male and female students differ on expectations of student leader consideration/support $(F(1,97)=10.64, \mathrm{p}<.01)$. Student females $(\mathrm{M}=23.1)$ expect 
significantly more consideration and support from student leaders than do their male counterparts $(M=21.7)$.

Adult Leader as Target. Results of the 3(Role) $x$ 4(Activity) MANOVA revealed significant effects by activity (Wilks' $\Lambda=.56, F(24,366)=3.33, \mathrm{p}<.001$ ) on expectations for adult leaders (see Table 8).

The univariate analysis for activity shows that subjects' expectations differ in three areas of adult leader behavior: accepting responsibility $(F(3,133)=4.18, p<.01)$, motivation $(\mathrm{F}(3,133)=3.51, \mathrm{p}<.05)$, and initiating structure $(\mathrm{F}(3,133)=8.67, \mathrm{p}<.001)$. Bonferroni's post-hoc procedure was used to establish significant activity group differences in expectations of adult leaders (see Table 9).

Members of Student Government (M=21.9) had significantly lower expectations of adult leaders for accepting responsibility/showing confidence than both Basketball Team (M=23.2) members and Band members $(M=23.3)$. Journalism group members $(\mathrm{M}=22.1)$ also had lower expectations than Band members in this area.

Expectations for adult leaders as motivators or goal setters was significantly lower for Student Government members $(M=22.4)$ than for both Basketball Team members $(M=23.9)$ and Band members $(M=24.0)$.

Student Government $(M=20.2)$ and Journalism $(M=20.2)$ group members had lower expectations of adult leaders initiating structure within the group than did Band $(\mathrm{M}=22.6)$ and Basketball Team members $(\mathrm{M}=22.7)$. 
A MANOVA testing differences by student gender was not significant, $\mathrm{F}(8,90)=1.18, \mathrm{~ns}$.

General Leader as Target. The 3(Role) x4(Activity) MANOVA found significant effects by role (Wilks' $\Lambda=.80, F(16,248)=1.81, \mathrm{p}<.05$ ) on expectations for leaders in general; see Table 10. The univariate analysis for role shows that subjects significantly differ on expectations of consideration/support $(F(2,131)=4.34, p<.05)$ of leaders in general. Specifically, those who are student activity group members $(M=22.6)$ expect significantly more consideration and support from leaders in general than do adult leaders $(\mathrm{M}=21.2)$.

A MANOVA testing differences by student gender was significant, $F(8,90)=2.04, p<.05$; see Table 11. Student females $(M=23.2)$ expect more consideration and support $(\mathrm{F}=10.5(1,97), \mathrm{p}<.01)$ than do student males $(\mathrm{M}=21.5)$. Student females $(M=22.0)$ also expect more problem solving or decision making behavior $(\mathrm{F}=6.31(1,97), \mathrm{p}<.05)$ from leaders in general than do student males $(M=20.5)$.

Differences in Student Expectations of Targets. A repeated measures analysis of variance (i.e., a within subjects design) was performed on each group of similar construct variables (e.g. slconsid, alconsid, glconsid). The analysis was performed using only student subjects $(\mathrm{N}=106)$. The purpose of this analysis was to determine if students (i.e. pooled across roles and activities) have different leader expectations for different types of leaders. For example, do students expect more, less, or the same 
amount of consideration and support from student leaders, adult leaders, and leaders in general?

The repeated measures analysis (see Table 12) revealed that student expectations differed, depending on the type of leader (target), for motivation $(\mathrm{F}(2,210)=4.02 \mathrm{p}<.05)$, initiating structure $(\mathrm{F}(2,210)=14.87, \mathrm{p}<.001)$, problem solving $(\mathrm{F}(2,210)=4.57, \mathrm{p}<.05)$, networking $(\mathrm{F}(2,210)=9.10, \mathrm{p}<.001)$, and expertise $(\mathrm{F}(2,210)=12.75, \mathrm{p}<.001) . T$-tests for paired samples (see Table 13) gave the following significant results.

Students expected significantly higher levels of motivation $\left(\mathrm{M}_{\mathrm{a}}=23.2\right.$, $\left.M_{s}=22.6\right)$, initiating structure $\left(M_{a}=21.2, M_{s}=19.6\right)$, problems solving $\left(M_{a}=21.7\right.$, $\left.M_{s}=21.0\right)$, networking $\left(M_{a}=20.6, M_{s}=19.5\right)$, and expertise $\left(M_{a}=20.8, M_{s}=19.7\right)$ from adult leaders than from student leaders.

Students also expected significantly higher levels of initiating structure $\left(\mathrm{M}_{\mathrm{g}}=20.4, \mathrm{M}_{\mathrm{s}}=19.6\right)$, problem solving $\left(\mathrm{M}_{\mathrm{g}}=21.5, \mathrm{M}_{\mathrm{s}}=21.0\right)$, networking $\left(\mathrm{M}_{\mathrm{g}}=20.0\right.$, $\left.M_{s}=19.5\right)$, and expertise $\left(M_{g}=21.0, M_{s}=19.7\right)$ from leaders in general than from student leaders.

Finally, students expected higher levels of initiating structure $\left(\mathrm{M}_{\mathrm{a}}=21.2\right.$, $\left.\mathrm{M}_{\mathrm{g}}=20.4\right)$ and networking $\left(\mathrm{M}_{\mathrm{a}}=20.6, \mathrm{M}_{\mathrm{g}}=20.0\right)$ from adult leaders than from leaders in general. 


\section{DISCUSSION}

The purpose of this study was to determine if the type of activity in which a person is involved affects his or her leadership expectations for student leaders, adult leaders, and leaders in general. The study was also intended to determine if a person's role as adult advisor, student leader, or student as group member influences expectations for these leaders. Analyses were also made to determine whether or not student gender made a difference in expectations of idealized leaders. Finally, analyses of all students' ratings were analyzed by the type of leader as a target for each leadership construct.

To clarify the discussion of these results, the impact of participating in a particular student activity will be discussed first. Next, role as a student leader or group member will be discussed, then gender differences will be evaluated. Finally, results for within subjects analyses by type of leader rated as a target will be discussed. The discussion concludes with suggestions for future research.

Impact of Extracurricular Activities. Participation in a particular type of group activity plays no role in subjects' expectations of leaders when they consider leaders "in general." Activity plays a very small role in subjects' expectations of student leaders. Specifically, only one difference was found in that people involved in Journalism expect more problem solving behavior from student leaders than people involved in Band. 
In contrast, activity has a major influence on expectations of adult leaders. Differences in expectations appear in the areas of accepting responsibility and acting confident, motivating the group and keeping them focused, and structuring group procedures and activities. Those involved in Band and Basketball Teams expect more from their adult leaders in each of these three areas than do those involved in Student Government. People associated with Band and Basketball also look for their adult leaders to provide more structure than do Journalism participants. Finally, individuals involved in Band expect their adult leaders to display more confidence than individuals involved in Journalism expect of their leaders.

The results suggest that individuals in Basketball and Band hold similar expectations of adult leaders in the areas of initiating structure, responsibility, and motivation. To a slightly lesser extent, Student Government and Journalism students are also similar in their expectations in these areas (see Table 9). Why do Basketball and Band members expect more behavior reflecting initiating structure, responsibility, and motivation from their adult leaders? One possible explanation lies in the similar characteristics of their activities.

Band and Basketball practices are organized in very similar fashions. For both activities, a practice session typically contains the following elements: 
Band

Warm-up: Scales, long tones

Drill: $\quad$ Arpeggios, etudes

Isolate: Sectionals, passages

Simulate: Play entire piece $\underline{\text { Basketball }}$

Stretching, jogging

Layups, passing

Run through plays

Scrimmage

The point is that both these activities are highly structured and the structure is initiated by the band director or basketball coach. Students and student leaders of these groups have little input into the customary structure of their activities.

This is in contrast to Journalism and Student Government students and student leaders, who are given much more freedom to guide the structure of their meetings and their day to day activities. The adult leaders in these groups more often act as an advisor or mentor. This could account for the higher expectations of initiating structure for band directors and basketball coaches over the adult leaders of the other groups.

This may also account for the higher expectations of responsibility for basketball coaches and band directors. They have more control over their group members' activities and with control comes responsibility. Leaders are held to a higher degree of accountability than others in the group (Hollander, 1978) despite any mitigating circumstances. For example, coaches are often held responsible for their team's win-loss record, even in seasons that include injuries to key players. Also, through neighborhood performances, games, and the local press, coaches and band 
directors attain a higher degree of visibility and recognition. Thus, to some extent their responsibility extends to the community.

What do these findings imply for leadership education? Student leaders who are involved in athletic or performance groups may not have the same opportunities to develop organizational skills through experience in initiating structure. For these leaders, special emphasis could be placed on increasing proficiency in developing, planning, and organizing group activities. For example, coaches and band directors could delegate student leaders to create a practice or rehearsal schedule one day a week or help develop guidelines for group members. Team captains could be taught skills in play calling and drum majors could be taught skills in marching band show design. Of course, some adult leaders may be reluctant to relinquish such duties to student leaders because the adult leaders are ultimately held responsible for group actions.

One aspect of Bands and Basketball Teams that may help explain why students expect more motivational behaviors from their adult leaders is that they are both oriented toward competition and performance. Bands are especially competitive at the 4A high school level. Marching, symphonic, and jazz band contests are held year around. Coaches and band directors must be adept and innovative to motivate their group members to practice hard on a daily basis. They must keep the group focused and get them "pumped up" before a competition. 
Student Government on the other hand is oriented toward service. While some motivation is required of Student Government adult leaders, it would seem unlikely that it matches the level of necessity or intensity of coaches and band directors.

To this point, explanations for differences in students' expectations of adult leaders have been offered based upon the nature of the activities. One could also suppose that the differences are due to the characteristics of the students. To a great degree, students self-select themselves for membership into their activity groups. Is there something about the type of student who joins marching band that is different than the type of student who joins the newspaper staff such that this difference is the root of their contrast in leadership expectations? Further studies might include examining expectations of students that are involved in more than one group -- for example, students involved in both Band and Journalism.

Impact of Role as Student Leader. The only role effect found was that student group members (nonleaders) expect more support and consideration from "leaders in general" than do adult leaders.

Surprisingly, students' roles have no effect on their expectations for what good student or adult leadership is. Student leaders and student group members (i.e., followers) have the same expectations of what makes an ideal leader. Leadership experience does not change students' perceptions about leadership. 
What implications are to be made for leadership education based upon these findings? Perhaps rather than emphasizing leadership experience, leadership curricula should emphasize experience in different groups (e.g., competitive groups, problem solving groups, creative groups) since activity does make a difference. Certainly, leadership experience is valuable for students. It gives them an opportunity to practice their skills (i.e., leader behaviors). However, adult activity leaders and leadership educators would be wise to encourage student leaders to broaden their interests through acting as followers in other activities. This would give student leaders exposure to a variety of adult and student leader role models and an assortment of group cultures, norms, and processes. Such experiences would give the student a more extensive view of what it means to be a good leader, while giving the adult activity leader a more complete student leader in return.

Impact of Gender Differences. Few differences were found between males and females expectations of their leaders. One difference of note was that females expect more support and consideration from student leaders and leaders in general (but not from adult leaders) than do males.

The sex-role stereotype of women as leaders includes the expectation that female leaders will be more considerate than male leaders (Petty \& Lee, 1975). In general, this stereotype is held by both women and men. (While the validity of this stereotype is supported in laboratory experiments and assessment studies, it is not supported in organizational studies (See Eagly \& Johnson (1990) for a meta-analysis 
Student and Adult Leadership Expectations

of this literature). In the present study, however, there is no gender attached to the idealized target leaders. Why would females expect more consideration from student leaders and leaders in general, and not from adult leaders? A possible answer to this question is offered in two parts.

First, cognitive prototypes are developed through experience. Occupations are sex-typed when the majority of those in a particular occupation are of one sex (Schein, 1973). For example, the normative expectations of a commercial airline pilot include an expectation that the pilot is male.

In the present study, 32 of the 39 adult leader subjects reported their sex. Of those 32, twenty-four (75\%) were males (see Table 1b). All basketball coaches and band directors were male. A slight majority of journalism instructors were male. Only in student government were there slightly more female adult leaders than male adult leaders. Therefore, it seems likely that the prototype of the adult leader is that of a male for the majority of subjects.

However, in the case of student leaders, the number of female and male leaders was even in student government, slightly greater for females in band and basketball, and much greater for females in journalism. (Note that, theoretically, the number of female and male student leaders should be equal in the case of basketball teams. Teams are composed entirely of either male or female players.) The point here is that with a greater balance of student leader gender, student leader prototypes are less likely to be sex-stereotyped. 
In the case of the "leader in general", it difficult to say whether subjects attach a specific gender to this leader. The nature of this target leader is ambiguous.

The second part to the explanation of why females expect more consideration involves a hypothesized link between the sex of the subject and the sex associated with the idealized leader. If both male subjects' and female subjects' prototypes of adult leaders includes a male sex-stereotype, then we would see no difference in their expectations of consideration. Indeed, in this study, no difference was found. However, in the case of student leaders and leaders in general, where there exists no sex-stereotype, we would see a difference in consideration expectation if female subjects' prototypes were more often female and male subjects' prototypes were more often male. In other words, in their contemplation of idealized student leaders or leaders in general, if females think of females and males think of males this would account for differences in expectations of consideration. The hypothesis that an individual's prototype of a nonsex-stereotyped occupation (e.g., teacher) or position (e.g., leader) is related to the sex of the individual holding the prototype is worth further investigation.

What are the implications of this finding (i.e., females expect more consideration from their student leaders than males) for leadership education? It is difficult to say until the underlying cause for such expectations is found. Student leaders could be made aware of this result, but how should they interpret it? Should they actually show more consideration toward females? 


\section{Differences Within Subjects on Types of Leaders Rated}

The analyses presented above examined differences between groups of subjects (i.e., roles, activities, gender) regarding their leadership expectations of a specific leader target. The following analyses examined differences within subjects' expectations of leadership between the three target leaders. Specifically, the second set of analyses were performed to see if students (student leaders and student group members combined) had different expectations of adult leaders, student leaders, and leaders in general.

Differences in student expectations of target leaders were found in several areas. Of special interest is the comparison of student expectations of adult and student leaders. The greatest difference in expectations is found in the area of initiating structure. Students feel that adult leaders should play a larger role in developing guidelines and procedures for the group than should student leaders. Students expect adults to be more involved in networking with those outside the group and coordinating outside arrangements and resources. They also expect adult leaders to have more knowledge and expertise than student leaders.

The three areas listed above appeal to common sense. It is natural to expect that adult leaders would have a greater hand in initiating structure and networking and have more expertise than student leaders. Student leaders generally change from year to year, while adult leaders are more stable in their roles. Aduits gain experience in those group processes, procedures, and strategies that work well and those that do not 
work as well. They build contacts with similar activity groups of other schools and with state and national organizations that support their activities. Adult leaders are likely to have a greater degree of expertise by being involved in their group activities for a greater number of years and through training classes and workshops.

It may be just as worthwhile to note the areas in which no significant differences were found in students' expectations of adult and student leaders: consideration, accepting responsibility, motivation, problem solving, and building teams. (Again, note that this analysis did not include the adult subjects and pooled all student leaders and student group members together.)

Knowledge of the similarities and differences in student expectations may help student and adult leaders more clearly define their roles. It may give them a starting point at the beginning of a school year to engage in dialogue pertaining to the meaning of their leadership positions. For example, while it has been demonstrated here that students' expectations of adult and student leaders are similar in terms of the motivation construct, the methods and strategies available to and used by adults may be quite different than those employed by student leaders. Adult and student leaders are likely to differ in their power bases.

\section{Future Research Directions}

Unfortunately, due to a low return rate, it was necessary to drop the Work group from the study. The generalizability of the present study must be limited to the school setting. A follow up study that included individuals working in a non-school 
setting could give insight into differences in leader expectations between adult teachers and adult managers. This information could be valuable in a program that readies students for their school-to-work transition.

Further studies might also differentiate between similar activity groups. For example, are expectations similar or different between basketball teams, football teams, and soccer teams? What about more individualized sports such as track, swimming, and wrestling?

While significant differences were found in several analyses, the magnitude of the differences were never great. The nature of the survey instrument may have had some influence here. Since all 40 statements listed on the survey were more or less positive it was expected that the distribution of responses would be somewhat skewed toward "Often" and "Always." The researcher was personally contacted by two subjects who asked, "If these are ideal leaders, shouldn't all the responses be 'Always'?" Indeed, a handful of surveys were returned where subjects chose the "Always" response most of the time.

\section{Summary}

In conclusion, this exploratory study provides some initial evidence that the type of high school activity in which one is involved has some influence on one's expectations of adult leadership behavior. Results also indicate that gender may influence leadership expectations of student leaders and leaders in general. Finally, this study suggests that students expect adult leaders to play a larger role than student 
Student and Adult Leadership Expectations

leaders in structuring group activities and networking with outside resources. They also expect adult leaders to possess a greater degree of expertise than student leaders in areas pertaining to the group's main tasks. Future research is needed to confirm this study's results, provide explanations based on quantitative methods, and explore student and leadership perceptions in work settings. 
Student and Adult Leadership Expectations

\section{REFERENCES}

Bass, B. M. (1990). Bass \& Stogdill's handbook of leadership: Theory, research, and managerial applications (3rd ed.). New York: The Free Press.

Calder, B. (1977). The attribution theory of leadership. In B. M. Staw \& G. R. Salancik (Ed.), New directions in organizational behavior (pp. 179-204). Chicago, IL: St. Clair Press.

Eagly, A. H., \& Johnson, B. T. (1990). Gender and leadership style: A metaanalysis. Psychological Bulletin, 108, 233-256.

Eden, D., \& Leviatan, U. (1975). Implicit leadership theory as a determinant of the factor structure underlying supervisory behavior scales. Journal of Applied Psychology, 60, 736-741.

Findorff, J. (1991). Providing students with leadership training programs. NASSP Bulletin, $\underline{75}, 87-89$.

Gano, M. (1993). Looking inward, reaching outward, stretching upward: A high school leadership class curriculum. Salem, OR: Oregon Association of Student Councils.

Hays, W. L. (1991). Statistics (4th ed.). Austin, TX: Harcourt, Brace, \& Jovanovich.

Hollander, E. P. (1978). Leadership dynamics: A practical guide to effective relationships. New York: Free Press. 
Student and Adult Leadership Expectations

Hymowitz, C., \& Schellhardt, T.D. (1986). The glass ceiling: Why women can't seem to break the invisible barrier that blocks them from the top jobs. Wall Street Journal, Section 4, 1, 4-5.

Magoon, R. A. (1981). A proposed model for leadership development. Roeper Review, 3 , 7-9.

Nye, J. L., \& Forsyth, D. R. (1991). The effects of prototype-based biases on leadership appraisals: A test of leadership categorization theory. Small Group Research, 22, 360-379.

Parker, J. P. (1983). The leadership training model. G/C/T, Sept./Oct., 8-13.

Petty, M. M., \& Lee, G. K. (1975). Moderating effects of sex of supervisor and subordinate on relationships between supervisory behavior and subordinate satisfaction. Journal of Applied Psychology, 60, 624-628.

Pfeffer, J. (1977). The ambiguity of leadership. The Academy of Management Review, 2, 104-112.

Porter, P. D. (1981). We should be teaching leadership skills and competencies. NASSP Bulletin, 65, 76-80.

Rush, M. C., Thomas, J. C., \& Lord, R. G. (1977). Implicit leadership theory: A potential threat to the internal validity of leader behavior questionnaires. Organizational Behavior and Human Performance, 20, 93-110.

Schein, V. E. (1973). The relationship between sex role stereotypes and requisite management characteristics. Journal of Applied Psychology, 57, 95-100. 
Simmons, N. (1983, November 13). Groups now teaching students how to lead. The New York Times, XII, pp. 59-60.

Stiles, D. A. (1986). Leadership training for high school girls: An intervention at one school. Journal of Counseling and Development, 65, 211-212.

Stogdill, R. M. (1963). Manual for the leader behavior description questionnaire Form XII. Columbus, OH: Ohio State University, Bureau of Business Research.

U.S. Department of Labor - The Secretary's Commission on Achieving Necessary Skills (1991). What Work Requires of Schools. Washington, DC: U.S. Government Printing Office.

Washburn, J. M., \& Hammond, J. M (1982). Student leadership camp for improving school climate. Educational Leadership, 39, 518-520.

Young, S. (1977). Developing a leadership class. Reston, VA: National Association of Secondary School Principals.

Yukl, G. A. (1989). Leadership in organizations. Englewood Cliffs, NJ: PrenticeHall. 


\section{APPENDIX A}

Leadership constructs and statements.

\section{Consideration.}

Is friendly and approachable.

Is concerned with the welfare of group members.

Listens carefully to group member's ideas and problems.

Puts suggestions made by the group into action.

Treats all group members as his or her equal.

\section{Accepting responsibility.}

Believes that he or she can get the job done.

Accepts responsibility for his or her actions.

Is willing to take risks.

Has faith in himself or herself.

Trusts his or her own instincts.

\section{Motivating.}

Tries to bring out the best work of group members.

Keeps the group members focused on their goal.

Maintains high standards.

Keeps the group members working at peak performance.

Encourages the group to continually do better.

\section{Initiating structure.}

Lets group members know what is expected of them.

Determines what shall be done and how it shall be done.

Asks group members to follow standard rules.

Develops guidelines or rules for group behavior.

Decides when and where the group will meet. 


\section{Problem solving.}

Weighs all the options before making a decision.

Comes up with many different solutions to a problem.

Develops strategies to solve problems.

Anticipates and responds quickly to problems.

Removes obstacles that get in the way of doing the job.

\section{Networking.}

Speaks for the group when visitors are present.

Uses available outside resources.

Makes necessary arrangements with those outside the group.

Publicizes the activities of the group.

Talks with others on behalf of the group.

\section{Building teams.}

Gets group members to work together.

Encourages teamwork.

Encourages group members to offer and exchange ideas.

Helps group members settle differences.

Keeps the group united.

\section{Expertise.}

Is among the best at the group's task.

Is very knowledgeable of the task at hand.

Can tell the difference between good and bad work.

Is one of the most gifted and talented of the group members.

Is highly skilled at performing the group's work. 
Student and Adult Leadership Expectations

\section{APPENDIX B}

Table 1a

Subject Totals by Role and Activity

\begin{tabular}{l|c|c|c|c|c|} 
& Basketball & Journalism & Student Govt. & Band & Role Total \\
\hline $\begin{array}{l}\text { Adult } \\
\text { Leader }\end{array}$ & 10 & 11 & 9 & 9 \\
$\begin{array}{l}\text { Student } \\
\text { Leader }\end{array}$ & 8 & 10 & 5 & 9 & 32 \\
\cline { 2 - 5 } $\begin{array}{l}\text { Group } \\
\text { Member }\end{array}$ & 17 & 24 & 19 & 14 & 74 \\
\hline $\begin{array}{l}\text { Activity } \\
\text { Total }\end{array}$ & 35 & 45 & 33 & 32 & 145
\end{tabular}

Table $1 \mathrm{~b}$

Subject Gender Totals by Role and Activity

\begin{tabular}{l|c|c|c|c|c|c|} 
& \multicolumn{2}{|c|}{ Adult } & Leader & \multicolumn{2}{c|}{ Student } & \multicolumn{2}{c|}{ Leader } & \multicolumn{2}{c|}{ Student } & \multicolumn{1}{c|}{ Grp.Mem. } \\
\cline { 2 - 7 } & Male & Female & Male & Female & Male & Female \\
\hline \multirow{2}{*}{$\begin{array}{l}\text { Basketball } \\
\text { Journalism }\end{array}$} & 9 & 0 & 3 & 5 & 5 & 10 \\
\cline { 2 - 7 } & 5 & 3 & 2 & 7 & 6 & 18 \\
\cline { 2 - 7 } Stdnt. Gov. & 3 & 5 & 2 & 2 & 4 & 12 \\
\cline { 2 - 7 } Band & 7 & 0 & 4 & 5 & 5 & 9 \\
\hline Total & 24 & 8 & 11 & 19 & 20 & 49
\end{tabular}

Note: Fourteen subjects did not indicate their gender on their survey: 7 adult leaders, 2 student leaders, and 5 student group members. 
Student and Adult Leadership Expectations

Table 2

Descriptive Statistics, Reliabilities, and Intercorrelations for Student Leader as Target

\begin{tabular}{||l|c|c|c|c|c|c|c|c|c|c||}
\hline \hline Student Target & $\mathrm{M}$ & $\mathrm{SD}$ & $\alpha$ & 1 & 2 & 3 & 4 & 5 & 6 & 7 \\
\hline 1. Consideration & 22.3 & 2.15 & .66 & & & & & & & \\
\hline 2. Responsibility & 22.1 & 1.81 & .57 & .45 & & & & & & \\
\hline 3. Motivation & 22.5 & 1.99 & .71 & .50 & .36 & & & & & \\
\hline 4. Initiate Structure & 19.4 & 2.60 & .62 & .18 & .35 & .38 & & & & \\
\hline 5. Problem Solving & 20.7 & 2.36 & .69 & .53 & .35 & .48 & .48 & & & \\
\hline 6. Network & 19.1 & 2.57 & .64 & .32 & .31 & .18 & .58 & .54 & & \\
\hline 7. Build Teams & 21.7 & 2.37 & .72 & .64 & .42 & .60 & .35 & .60 & .45 & \\
\hline 8. Expertise & 19.7 & 2.73 & .74 & .13 & .44 & .27 & .57 & .37 & .33 & .16 \\
\hline
\end{tabular}

$N=143$ 
Student and Adult Leadership Expectations

Table 3

Descriptive Statistics, Reliabilities, and Intercorrelations for Adult Leader as Target

\begin{tabular}{||l|c|c|c|c|c|c|c|c|c|c||}
\hline \hline Adult Target & $\mathrm{M}$ & $\mathrm{SD}$ & $\alpha$ & 1 & 2 & 3 & 4 & 5 & 6 & 7 \\
\hline 1. Consideration & 22.9 & 2.66 & .71 & & & & & & & \\
\hline 2. Responsibility & 22.6 & 2.00 & .63 & .57 & & & & & & \\
\hline 3. Motivation & 23.2 & 2.36 & .82 & .63 & .60 & & & & & \\
\hline 4. Initiate Structure & 21.3 & 2.86 & .75 & .40 & .56 & .70 & & & & \\
\hline 5. Problem Solving & 21.9 & 2.52 & .75 & .47 & .65 & .57 & .64 & & & \\
\hline 6. Network & 20.5 & 2.90 & .73 & .38 & .52 & .47 & .65 & .61 & & \\
\hline 7. Build Teams & 22.2 & 2.63 & .75 & .71 & .59 & .67 & .59 & .62 & .55 & \\
\hline 8. Expertise & 20.9 & 3.51 & .86 & .37 & .62 & .39 & .47 & .55 & .48 & .41 \\
\hline
\end{tabular}

$\mathrm{N}=145$ 
Student and Adult Leadership Expectations

Table 4

Descriptive Statistics, Reliabilities, and Intercorrelations for Leaders in General as Target

\begin{tabular}{||l|c|c|c|c|c|c|c|c|c|c||}
\hline General Target & $\mathrm{M}$ & $\mathrm{SD}$ & $\alpha$ & 1 & 2 & 3 & 4 & 5 & 6 & 7 \\
\hline 1. Consideration & 22.3 & 2.49 & .76 & & & & & & & \\
\hline 2. Responsibility & 22.5 & 2.11 & .68 & .59 & & & & & & \\
\hline 3. Motivation & 22.7 & 2.58 & .85 & .67 & .67 & & & & & \\
\hline 4. Initiate Structure & 20.4 & 2.84 & .75 & .35 & .41 & .53 & & & & \\
\hline 5. Problem Solving & 22.6 & 2.67 & .82 & .67 & .60 & .63 & .57 & & & \\
\hline 6. Network & 19.9 & 2.83 & .73 & .50 & .41 & .47 & .69 & .66 & & \\
\hline 7. Build Teams & 22.0 & 2.59 & .78 & .70 & .57 & .78 & .59 & .70 & .66 & \\
\hline 8. Expertise & 20.8 & 3.09 & .83 & .28 & .37 & .32 & .52 & .44 & .50 & .37 \\
\hline
\end{tabular}

$\mathrm{N}=143$ 
Table 5

Leadership Expectation Variables

Ideal Leader as Target

\begin{tabular}{|c|c|c|c|}
\hline & Student & $\underline{\text { Adult }}$ & General \\
\hline Consideration/Support & slconsid & alconsid glconsid & \\
\hline Responsibility/Confidence & slrespns & alrespns glrespns & \\
\hline Motivating/Goals Setting & slmotivt & almotivt & glmotivt \\
\hline Initiating Structure & slinitst & alinitst & glinitst \\
\hline Problem Solving & slprbslv & alprbslv & glprbslv \\
\hline Networking/Coordinating slnetwr & & glnetwrl & \\
\hline Building Teams & slbldtms & albldtms & glbldtms \\
\hline Expertise & slexprts & alexprts & glexprts \\
\hline
\end{tabular}


Table 6

Multivariate Analysis of Variance Results (Student Leader as Target): 3(Role) x 4(Activity)

\begin{tabular}{|c|c|c|c|}
\hline & \multicolumn{3}{|c|}{ Wilks' } \\
\hline Effect & $\underline{\mathrm{Lam}}$ & & $\underline{\mathrm{df}}$ \\
\hline Role $\mathrm{x}$ Activity & .63 & $1.22, \mathrm{~ns}$ & 48,614 \\
\hline Activity & .74 & $1.63, p<.05$ & 24,360 \\
\hline Role & .82 & $1.63, \mathrm{~ns}$ & 16,248 \\
\hline
\end{tabular}

$N=143$

MANOVA Cell Means and Univariate Results

Activity

\begin{tabular}{|c|c|c|c|c|c|c|}
\hline Variable & Bball & Journ & StGov & Band & $\mathrm{E}$ & df \\
\hline slconsid & 22.4 & 22.5 & 22.3 & 21.6 & $1.57, \mathrm{~ns}$ & 3,131 \\
\hline sirespns & 22.4 & 21.7 & 22.0 & 22.2 & $0.72, \mathrm{~ns}$ & \\
\hline slmotivt & 22.8 & 22.6 & 22.2 & 22.5 & $1.12, \mathrm{~ns}$ & \\
\hline slinitst & 18.7 & 19.3 & 20.1 & 19.6 & $1.43, \mathrm{~ns}$ & \\
\hline slprbslv & 20.6 & 21.3 & 20.9 & 19.8 & $3.42, p<.05$ & \\
\hline slnetwrk & 18.8 & 18.9 & 19.8 & 18.6 & $1.20, \mathrm{~ns}$ & \\
\hline slbldtms & 22.0 & 21.6 & 21.9 & 20.9 & $0.98, \mathrm{~ns}$ & \\
\hline slexprts & 19.3 & 20.2 & 19.5 & 20.0 & $1.39, \mathrm{~ns}$ & \\
\hline
\end{tabular}

Table 7

Multivariate Analysis of Variance Results (Student Leader as Target): Gender Differences

\begin{tabular}{|c|c|c|c|c|}
\hline Effect & & $\begin{array}{l}\text { Wilks' } \\
\text { ' }\end{array}$ & & \\
\hline Student Gender & & $.84 \quad 2.16, p<.05$ & 8,90 & \\
\hline \multicolumn{5}{|l|}{$N=99$} \\
\hline \multicolumn{5}{|c|}{ Student Gender } \\
\hline Variable & Males & Females & $\mathrm{E}$ & $\underline{\mathrm{df}}$ \\
\hline slconsid & 21.7 & 23.1 & $10.64, p<.01$ & 1,97 \\
\hline slrespns & 22.5 & 22.2 & $0.58, \mathrm{~ns}$ & \\
\hline slmotivt & 22.5 & 22.7 & $0.29, \mathrm{~ns}$ & \\
\hline slinitst & 19.6 & 19.6 & $0.01, \mathrm{~ns}$ & \\
\hline slprbslv & 20.7 & 21.0 & $0.38, \mathrm{~ns}$ & \\
\hline slnetwrk & 19.1 & 19.4 & $0.23, \mathrm{~ns}$ & \\
\hline slbldtms & 21.5 & 22.2 & $1.73, \mathrm{~ns}$ & \\
\hline slexprts & 20.0 & 19.5 & $0.60, \mathrm{~ns}$ & \\
\hline
\end{tabular}


Student and Adult Leadership Expectations

Table 8

Multivariate Analysis of Variance Results (Adult Leader as Target): 3 (Role) $\times 4$ (Activity)

\begin{tabular}{|c|c|c|c|}
\hline & \multicolumn{3}{|c|}{ Wilks' } \\
\hline Effect & Lam & & df \\
\hline Role $\mathrm{x}$ Activity & .69 & $1.02, \mathrm{~ns}$ & 48,624 \\
\hline Activity & .56 & $3.33, \mathrm{p}<.001$ & 24,366 \\
\hline Role & .84 & 1.46 , ns & 16,252 \\
\hline
\end{tabular}

$\mathrm{N}=145$

MANOVA Cell Means and Univariate Results

Activity

$\begin{array}{lllllll}\text { Variable } & & \text { Bball } & \underline{\text { Journ }} & \underline{\text { StGov }} & \text { Band } & \text { E } \\ \text { alconsid } & 22.4 & 21.9 & 21.8 & 21.4 & & 1.44, \mathrm{~ns} \\ \text { alrespns } & 23.2 & 22.1 & 21.9 & 23.3 & & 4.18, \mathrm{p}<.01 \\ \text { almotivt } & & 23.9 & 22.7 & 22.4 & 24.0 & 3.51, \mathrm{p}<.05 \\ \text { alinitst } & & 22.7 & 20.2 & 20.2 & 22.6 & 8.67, \mathrm{p}<.001 \\ \text { alprbslv } & & 22.6 & 21.6 & 21.6 & 21.8 & 0.58, \mathrm{~ns} \\ \text { alnetwrk } & & 21.0 & 19.8 & 20.0 & 21.6 & 2.38, \mathrm{~ns} \\ \text { albldtms } & & 22.8 & 22.0 & 21.9 & 22.2 & 0.75, \mathrm{~ns} \\ \text { alexprts } & & 21.1 & 21.2 & 19.5 & 22.0 & 2.10, \mathrm{~ns}\end{array}$

Table 9

One-way ANOVA: Post-hoc (Bonferroni) Test. $\mathrm{p}<.05$

Variable

Activity

alrespns StGov (21.9)

Bball (23.2)

StGov (21.9)

Band (23.3)

Journ (22.1)

Band (23.3)

almotivt

StGov (22.4)

Bball (23.9)

StGov (22.4)

Band (24.0)

alinitst

$\begin{array}{ll}\text { Journ (20.2) } & \text { Band (22.6) } \\ \text { Journ (20.2) } & \text { Bball (22.7) } \\ \text { StGov (20.2) } & \text { Band (22.6) } \\ \text { StGov (20.2) } & \text { Bball (22.7) }\end{array}$


Table 10

Multivariate Analysis of Variance Results(Leaders in General as Target):3(Role)x4(Activity)

$\begin{array}{llll}\text { Effect } & \text { Wilks' } & \\ \text { Role } x \text { Activity } & \text { Lambda } & \text { df } \\ \text { Activity } & .73 & 0.86, \mathrm{~ns} & 48,614 \\ \text { Role } & .78 & 1.37, \mathrm{~ns} & 24,360 \\ & .80 & 1.81, \mathrm{p}<.05 & 16,248\end{array}$

$N=143$

MANOVA Cell Means and Univariate Results

Role

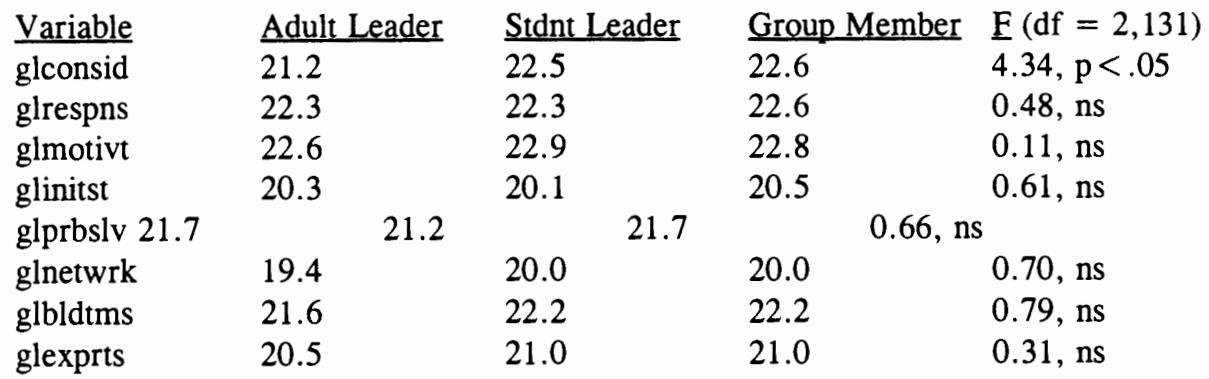

Table 11

Multivariate Analysis of Variance Results(Leaders in General as Target):Gender Differences

\begin{tabular}{lll} 
& Wilks' \\
Effect & $\frac{\text { Lambda }}{\mathrm{S}}$ & $\mathrm{E}$ \\
Student Gender & .85 & df \\
\hline & &
\end{tabular}

$\mathrm{N}=99$

Student Gender

\begin{tabular}{|c|c|c|c|}
\hline Variable & Males & Females & $\underline{F}(\mathrm{df}=1,97)$ \\
\hline glconsid & 21.5 & 23.2 & $10.05, p<.01$ \\
\hline glrespns & 22.5 & 22.7 & $0.12, \mathrm{~ns}$ \\
\hline glmotivt & 22.4 & 23.2 & $2.15, \mathrm{~ns}$ \\
\hline glinitst & \multirow{2}{*}{\multicolumn{2}{|c|}{22.0}} & $0.57, \mathrm{~ns}$ \\
\hline glprbslv 20.5 & & & $6.31, p<.05$ \\
\hline glnetwrk & 19.5 & 20.3 & $1.39, \mathrm{~ns}$ \\
\hline glbldtms & 21.7 & 22.5 & $1.64, \mathrm{~ns}$ \\
\hline glexprts & 20.9 & 20.9 & $0.00, \mathrm{~ns}$ \\
\hline
\end{tabular}


Student and Adult Leadership Expectations

Table 12

Repeated Measures Analysis on Students' Construct Ratings of Leadership Targets

$\begin{array}{lcc} & \mathrm{F} & \mathrm{df} \\ \text { Consideration } & 2.31, \mathrm{~ns} & 2,210 \\ \text { Responsibility } & 2.81, \mathrm{~ns} & 2,210 \\ \text { Motivation } & 4.02, \mathrm{p}<.05 & 2,210 \\ \text { Initiating Structure } & 14.87, \mathrm{p}<.001 & 2,210 \\ \text { Problem Solving } & 4.57, \mathrm{p}<.05 & 2,210 \\ \text { Networking } & 9.10, \mathrm{p}<.001 & 2,210 \\ \text { Building Teams } & 0.80, \mathrm{~ns} & 2,210 \\ \text { Expertise } & 12.75, \mathrm{p}<.001 & 2,210\end{array}$

$\mathrm{N}=106$ 
Student and Adult Leadership Expectations

Table 13

T-tests for Differences by Type of Leader as Target

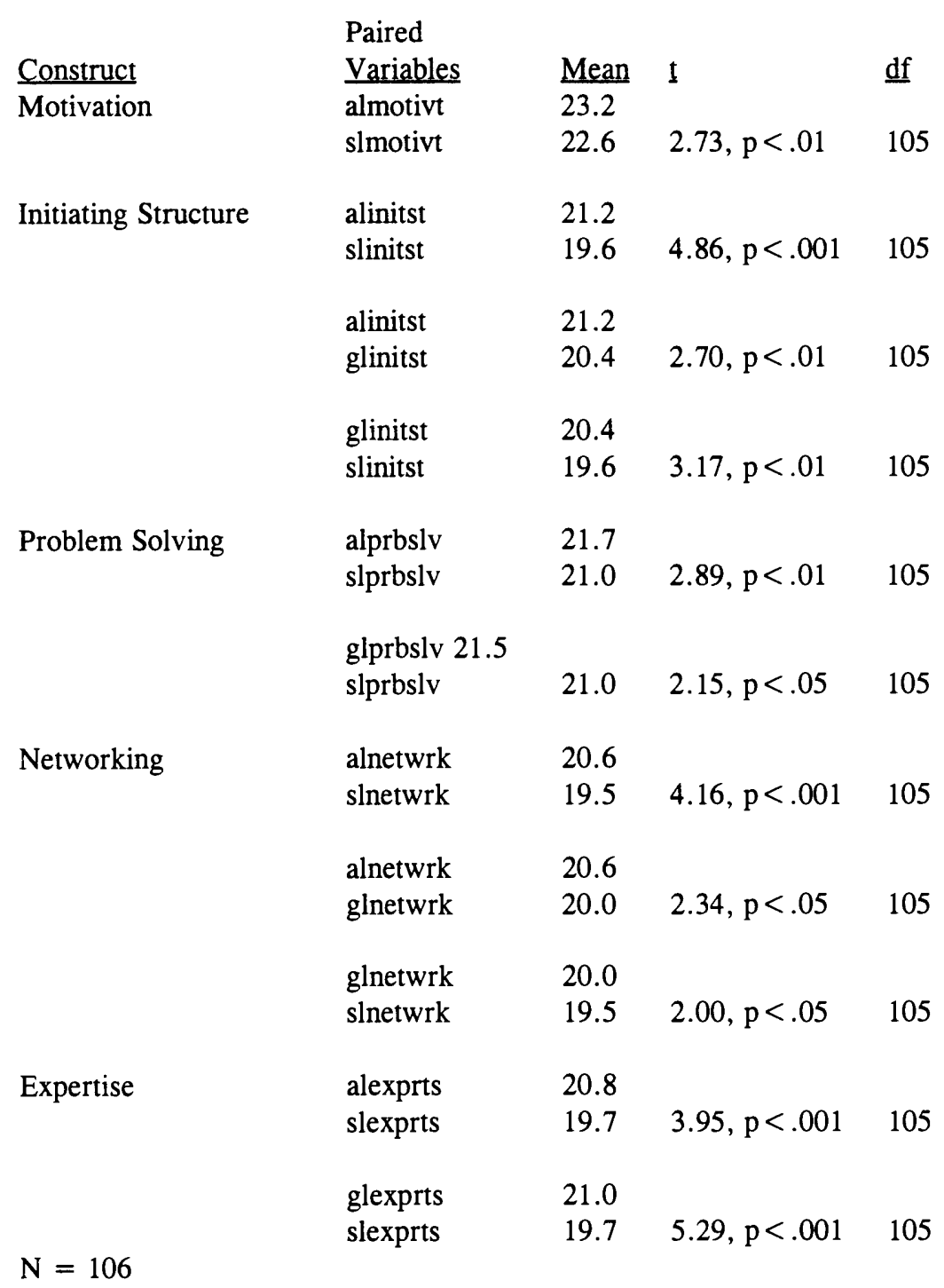

